\title{
Synthesis of Silver- and Gold-N-Heterocyclic Carbene Complexes Including Strong Metal-Carbon Binding
}

\section{Güçlü Metal-Karbon Bağı İçeren Gümüş- ve Altın-N-Heterosiklik Karben Komplekslerinin Sentezi}

\author{
Nazan Kaloğlu ${ }^{1,2 *}$ and İsmail Özdemir ${ }^{1,2}$ \\ ${ }^{1}$ Department of Chemistry, Faculty of Science and Arts, İnönü University, Malatya, Turkey. \\ ${ }^{2}$ Catalysis Research and Application Center, İnönü University, Malatya, Turkey.
}

\section{ABSTRACT}

\begin{abstract}
n this study, the new benzimidazolium salt (1) containing ether functionalized alkyl group as the NHC ligand precursor was synthesized. Ag-NHC complex (2) was synthesized by interaction with $\mathrm{Ag}_{2} \mathrm{O}$ of this ligand precursor. The Au-NHC complex was synthesized by interaction of the $\left[\mathrm{AuCl}\left(\mathrm{PPh}_{3}\right)\right]$ complex with the synthesized $\mathrm{Ag}-\mathrm{NHC}$ complex. The structures of prepared all new compounds were characterized by different spectroscopic methods.
\end{abstract}

\section{Key Words}

Benzimidazolium salt, gold, N-Heterocyclic carbene, silver.

\section{öz}

u çalışmada, NHC ligand öncüsü olarak eter fonksiyonlu alkil grubu içeren yeni benzimidazol tuzu (1) sentezlendi. Ag-

DHC kompleksi (2) bu ligand öncüsünün $\mathrm{Ag}_{2} \mathrm{O}$ ile etkileştirilmesiyle sentezlendi. Au-NHC kompleksi (3) sentezlenmiş $\mathrm{Ag}-\mathrm{NHC}$ kompleksi ile $\left[\mathrm{AuCl}\left(\mathrm{PPh}_{3}\right)\right]$ kompleksinin etkileştirilmesiyle sentezlendi. Hazırlanan tüm yeni bileşiklerin yapısı farklı spektroskopik metodlar ile karakterize edildi.

\section{Anahtar Kelimeler}

Altın, benzimidazolyum tuzu, N-Heterosiklik karben, gümüş.

Article History: Received: Oct 28, 2020; Revised: Mar 11, 2021; Accepted: May 11, 2021; Available Online: Jun $19,2021$. DOI: https://doi.org/10.15671/hjbc. 817435

Correspondence to: N. Kaloğlu, Catalysis Research and Application Center, İnönü University, Malatya, Turkey.

E-Mail: nzntemelli@hotmail.com 


\section{INTRODUCTION}

$N$ Heterocyclic carbenes (NHCs) are widely used as effective ligands in coordination chemistry. As $\mathrm{NHCs}$ are strong $\sigma$-donors, they make stable metalcarbon bonds. Therefore, metal-NHC complexes are used as strong, reactive and selective catalysts in many chemical reactions [1-3]. Although, metal-NHC complexes are widely used in organometallic chemistry and catalysis, these complexes prepared using different metals and different NHC ligands such as $\mathrm{Au}, \mathrm{Pd}, \mathrm{Cu}, \mathrm{Ru}, \mathrm{Pt}$, $\mathrm{Ag}$ and $\mathrm{Rh}$ are widely used in medical applications [4-9].

Some studies have shown that biological activity is not only dependent on the nature of the metal, but also on the structure of the ligand. Although, most of the drugs on the market are organic compounds and natural products, scientists today have shown an intense interest in the development of metal-based drugs and metalbased diagnostic agents. As far as their kinetic properties, based on different coordination numbers and geometries, metal-complexes have different mechanisms of drug action compared to organic compounds. This situation has made the synthesis of new and effective ligands, which are easy to prepare, open to modification, and which have a variety of structure, more important.

The use of transition-metal compounds in the treatment of various diseases dates back to the $18^{\text {th }}$ century [10]. Silver nitrate compound has been frequently used in the treatment of chronic skin and skin ulcers since the $18^{\text {th }}$ century [11]. Silver sulfadiazine used firstly in 1968, is a drug used in the treatment of burn wounds and is sold commercially in the form of cream containing 1-5\% silver sulfadiazine under various names [12]. Cisplatin, which has been used since 1969, is the most impressive example of platinum-based chemotherapeutic agents. Cisplatin has been shown to be effective in the treatment of ovarian, lung, neck, head and esophageal cancers. Cisplatin interacting with DNA in cancer cells, prevents cell division and slows the growth rate of cancer cells [13-15]. Auranofin, which has been used since 1985, is known for its antitumor properties, inhibits the thioredoxin reductase enzyme in cancer cells [16] (Figure 1).

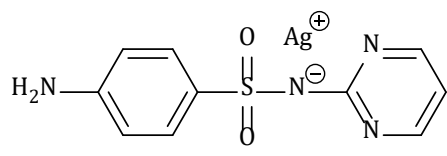

Silver sulfodiazin

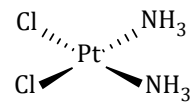

Cisplatin

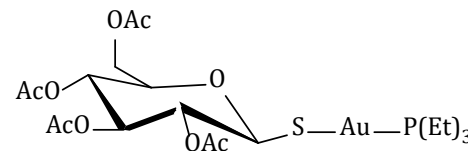

Auranofin

Figure 1. Some metalopharmaceutical agents used as commercially.

Although, the mechanisms of action are not fully understood, biological activity in silver complexes is ensured by the release of $\mathrm{Ag}^{+}$ions. The antimicrobial activity of Ag-NHC complexes was firstly investigated by Youngs [17]. It was observed that the synthesized $\mathrm{Ag}-\mathrm{NHC}$ complexes showed better antimicrobial activity than $\mathrm{AgNO}_{3}$. Following this study, the use of $\mathrm{NHC}$ complexes containing $\mathrm{Ag}, \mathrm{Au}, \mathrm{Pt}, \mathrm{Pd}$ and $\mathrm{Cu}$ metals in medical applications continued at an increasing rate. In this study, new benzimidazolium salt and its $\mathrm{Ag}-\mathrm{NHC}$ and $\mathrm{Au}-\mathrm{NHC}$ complexes were synthesized (Scheme 1). The structures of prepared all new compounds were characterized by different spectroscopic methods.

\section{MATERIALS and METHODS}

Benzimidazolium salt, $\mathrm{Ag}-\mathrm{NHC}$ and $\mathrm{Au}-\mathrm{NHC}$ complexes were carried out under argon using standard Schlenk line techniques. All chemicals and solvents were obtained from commercial sources and were of analytical grade and were used without further purifications. Melting points were measures in open capillary tubes with an Electrothermal-9200 melting points apparatus. Fourier transform infrared (FT-IR) spectra were obtainedin the range $450-4000 \mathrm{~cm}^{-1}$ on a Perkin Elmer Spectrum 100 Spectrophotometer. ${ }^{1} \mathrm{H}$ NMR and ${ }^{13} \mathrm{C}$ NMR spectra were recorded using a Bruker As 400 



Sheme 1. Synthesized benzimidazolium salt (1), Ag-NHC (2) and Au-NHC (3) complexes.

Mercury spectrometer operating at $400 \mathrm{MHz}\left({ }^{1} \mathrm{H}\right), 100$ $\mathrm{MHz}\left({ }^{13} \mathrm{C}\right)$ in $\mathrm{CDCl}_{3}$ with tetramethylsilane as the internal reference. ${ }^{1} \mathrm{H}$ peaks were labeled as singlet (s), doublet (d), triplet (t), quartet (q), quintet (quint.) and multiplet (m). ${ }^{1} \mathrm{H}$ NMR spectra are referenced to residual protiated solvents $\left(\delta=7.26 \mathrm{ppm}\right.$ for $\left.\mathrm{CDCl}_{3}\right),{ }^{13} \mathrm{C}$ chemical shifts are reported relative to deuterated solvents $(\delta=77.16$ ppm for $\mathrm{CDCl}_{3}$ ).

\section{RESULTS and DISCUSSION}

Synthesis of 1-(2-(2-Ethoxyphenoxy)ethyl)-3-(2,2diethoxyethyl)benzimidazolium bromide, (1)

$\mathrm{N}$-(2-(2-Ethoxyphenoxy)ethyl)benzimidazole (1.41 g, $5.0 \mathrm{mmol}$ ) was dissolved in DMF $(5 \mathrm{~mL})$ and 2,2-diethoxyethyl bromide $(0.98 \mathrm{~g}, 5.0 \mathrm{mmol})$ was added. The solution was stirred at $80^{\circ} \mathrm{C}$ for 24 hours. End of the reaction, the solvent was evaporated in vacuo and dissolved in $\mathrm{EtOH}(5 \mathrm{~mL})$. The solution was added to $\mathrm{Et}_{2} \mathrm{O}(15 \mathrm{~mL})$ and allowed to crystallize. The synthesized benzimidazolium salt was obtained as white crystalline solid with high yields. The structure of compound 1 was characterized ${ }^{1} \mathrm{H}$ and ${ }^{13} \mathrm{C}$ NMR spectroscopic methods (Table 1). (2.15 g, yield 90\%; m.p. = $146-147{ }^{\circ} \mathrm{C}$; FT-IR $\left(\mathrm{v}_{(\mathrm{CN})}=1559 \mathrm{~cm}^{-1}\right)$.

\section{Synthesis of [1-(2-(2-Ethoxyphenoxy)ethyl)-3-} (2,2-diethoxyethyl)benzimidazol-2-ylidene]silver(I) bromide, (2)

The synthesized (1) compound $(0.48 \mathrm{~g}, 1.0 \mathrm{mmol})$ was dissolved in dichloromethane $(15 \mathrm{~mL})$ and was added $\mathrm{Ag}_{2} \mathrm{O}(0.12 \mathrm{~g}, 0.5 \mathrm{mmol})$, and the solution was stirred at $25^{\circ} \mathrm{C}$ in dark condition for $24 \mathrm{~h}$. End of the reaction, the solution was filtered over Celite. Half of the solution was evaporated in vacuo and $\mathrm{Et}_{2} \mathrm{O}(15 \mathrm{~mL})$ was added to crystallize. The resulting white crystals were obtained in high yield. The structure of compound 1 was characterized by ${ }^{1} \mathrm{H}$ and ${ }^{13} \mathrm{C}$ NMR spectroscopic methods (Table 2). $\left(0.46 \mathrm{~g}\right.$, yield $78 \%$; m.p. $=191-192^{\circ} \mathrm{C} ; \mathrm{FT}-\mathrm{IR} \mathrm{v}_{(\mathrm{CN})}=$ $\left.1388 \mathrm{~cm}^{-1}\right)$. 
Table 1. ${ }^{1} \mathrm{H}$ and ${ }^{13} \mathrm{C}$ NMR data of compound (1).

\begin{tabular}{|c|c|c|c|}
\hline Position & ${ }^{1} \mathrm{H}$ NMR ( $\left.\delta \mathrm{ppm}\right)$ & ${ }^{13} \mathrm{C}$ NMR $(\delta \mathrm{ppm})$ & $J(H z)$ \\
\hline $\mathrm{NCH}_{2} \mathrm{CH}\left(\mathrm{OCH}_{2} \mathrm{CH}_{3}\right)_{2}$ & $1.13(\mathrm{t}, 6 \mathrm{H})$ & 15.17 & 7.0 \\
\hline $\mathrm{NCH}_{2} \mathrm{CH}_{2} \mathrm{OC}_{6} \mathrm{H}_{4}\left(\mathrm{OCH}_{2} \mathrm{CH}_{3}\right)-2$ & $1.38(t, 3 H)$ & 14.97 & 7.0 \\
\hline $\mathrm{NCH}_{2} \mathrm{CH}\left(\mathrm{OCH}_{2} \mathrm{CH}_{3}\right)_{2}$ & 3.66 and $3.78(\mathrm{dq}, 4 \mathrm{H})$ & 47.83 & 14.1 and 7.0 \\
\hline $\mathrm{NCH}_{2} \mathrm{CH}_{2} \mathrm{OC}_{6} \mathrm{H}_{4}\left(\mathrm{OCH}_{2} \mathrm{CH}_{3}\right)-2$ & $3.98(q, 2 H)$ & 50.09 & 7.0 \\
\hline $\mathrm{NCH}_{2} \mathrm{CH}_{2} \mathrm{OC}_{6} \mathrm{H}_{4}\left(\mathrm{OCH}_{2} \mathrm{CH}_{3}\right)-2$ & $4.56(t, 2 H)$ & 63.81 & 4.5 \\
\hline $\mathrm{NCH}_{2} \mathrm{CH}\left(\mathrm{OCH}_{2} \mathrm{CH}_{3}\right) 2$ & $4.71(\mathrm{~d}, 2 \mathrm{H})$ & 64.64 & 4.2 \\
\hline $\mathrm{NCH}_{2} \mathrm{CH}\left(\mathrm{OCH}_{2} \mathrm{CH}_{3}\right) 2$ & $5.04(t, 1 H)$ & 68.23 & 4.2 \\
\hline $\mathrm{NCH}_{2} \mathrm{CH}_{2} \mathrm{OC}_{6} \mathrm{H}_{4}\left(\mathrm{OCH}_{2} \mathrm{CH}_{3}\right)-2$ & $5.17(t, 2 H)$ & 100.04 & 4.4 \\
\hline $\begin{array}{c}\text { Hs and Cs of benzimidazole and } \\
\text { phenoxy rings }\end{array}$ & $\begin{array}{c}\text { 6.81-6.94, 7.59-7.64, } \\
\text { 7.81-7.83 and } 8.17-8.19(\mathrm{~m}, \\
8 \mathrm{H})\end{array}$ & $\begin{array}{c}112.72,114.05,114.51 \\
114.80,120.82,122.90 \\
126.74,126.86,132.07 \\
132.12,147.13 \text { and } 148.71\end{array}$ & - \\
\hline $\begin{array}{l}\text { acidic } \mathrm{C}(2)-\mathrm{H} \text { proton of } \\
\text { benzimidazole rings }\end{array}$ & $11.22(s, 1 H)$ & 143.57 & - \\
\hline
\end{tabular}

Table 2. ${ }^{1} \mathrm{H}$ and ${ }^{13} \mathrm{C}$ NMR data of compound (2).

\begin{tabular}{|c|c|c|c|}
\hline Position & ${ }^{1} \mathrm{H}$ NMR $(\delta \mathrm{ppm})$ & ${ }^{13} \mathrm{C} N M R(\delta p p m)$ & $J(H z)$ \\
\hline $\mathrm{NCH}_{2} \mathrm{CH}\left(\mathrm{OCH}_{2} \mathrm{CH}_{3}\right)_{2}$ & $1.02(t, 6 \mathrm{H})$ & 15.01 & 7.0 \\
\hline $\mathrm{NCH}_{2} \mathrm{CH}_{2} \mathrm{OC}_{6} \mathrm{H}_{4}\left(\mathrm{OCH}_{2} \mathrm{CH}_{3}\right)-2$ & $1.31(t, 3 H)$ & 15.21 & 7.0 \\
\hline $\mathrm{NCH}_{2} \mathrm{CH}\left(\mathrm{OCH}_{2} \mathrm{CH}_{3}\right)_{2}$ & 3.39 and $3.66(\mathrm{dq}, 4 \mathrm{H})$ & 49.47 & 9.2 and 7.0 \\
\hline $\mathrm{NCH}_{2} \mathrm{CH}_{2} \mathrm{OC}_{6} \mathrm{H}_{4}\left(\mathrm{OCH}_{2} \mathrm{CH}_{3}\right)-2$ & $3.90(q, 2 H)$ & 52.37 & 6.9 \\
\hline $\mathrm{NCH}_{2} \mathrm{CH}_{2} \mathrm{OC}_{6} \mathrm{H}_{4}\left(\mathrm{OCH}_{2} \mathrm{CH}_{3}\right)-2$ & $4.37(t, 2 H)$ & 63.92 & 4.9 \\
\hline $\mathrm{NCH}_{2} \mathrm{CH}\left(\mathrm{OCH}_{2} \mathrm{CH}_{3}\right) 2$ & $4.73(t, 2 \mathrm{H})$ & 64.31 & 5.1 \\
\hline $\mathrm{NCH}_{2} \mathrm{CH}\left(\mathrm{OCH}_{2} \mathrm{CH}_{3}\right) 2$ & $4.78(t, 1 H)$ & 69.14 & 4.8 \\
\hline $\mathrm{NCH}_{2} \mathrm{CH}_{2} \mathrm{OC}_{6} \mathrm{H}_{4}\left(\mathrm{OCH}_{2} \mathrm{CH}_{3}\right)-2$ & $8.05(\mathrm{dd}, 2 \mathrm{H})$ & 102.26 & 7.5 \\
\hline $\begin{array}{c}\text { Hs and Cs of benzimidazole and } \\
\text { phenoxy rings }\end{array}$ & $\begin{array}{l}6.73-6.83,7.29-7.35,7.54- \\
7.56 \text { and } 7.77-7.79(\mathrm{~m}, 8 \mathrm{H})\end{array}$ & $\begin{array}{c}\text { 112.58, 112.71, 112.94, } \\
\text { 113.95, 120.74, 122.16, } \\
\text { 123.95, 124.10, 134.47, } \\
134.57,147.59 \text { and } 148.81\end{array}$ & - \\
\hline $\mathrm{Ag}-\mathrm{C}(2)_{\text {carbene }}$ & - & 188.83 & - \\
\hline
\end{tabular}


Table 3. ${ }^{1} \mathrm{H}$ and ${ }^{13} \mathrm{C}$ NMR data of compound (3).

\begin{tabular}{|c|c|c|c|}
\hline Position & ${ }^{1} \mathrm{H}$ NMR $(\delta \mathrm{ppm})$ & ${ }^{13} \mathrm{CNMR}(\delta \mathrm{ppm})$ & $J(H z)$ \\
\hline $\mathrm{NCH}_{2} \mathrm{CH}\left(\mathrm{OCH}_{2} \mathrm{CH}_{3}\right)_{2}$ & $0.97(t, 6 \mathrm{H})$ & 14.92 & 7.0 \\
\hline $\mathrm{NCH}_{2} \mathrm{CH}_{2} \mathrm{OC}_{6} \mathrm{H}_{4}\left(\mathrm{OCH}_{2} \mathrm{CH}_{3}\right)-2$ & $1.17(t, 3 H)$ & 15.35 & 7.0 \\
\hline $\mathrm{NCH}_{2} \mathrm{CH}\left(\mathrm{OCH}_{2} \mathrm{CH}_{3}\right)_{2}$ & 3.43 and $3.69(\mathrm{dq}, 4 \mathrm{H})$ & 49.09 & 14.1 and 7.1 \\
\hline $\mathrm{NCH}_{2} \mathrm{CH}_{2} \mathrm{OC}_{6} \mathrm{H}_{4}\left(\mathrm{OCH}_{2} \mathrm{CH}_{3}\right)-2$ & $3.79(q, 2 H)$ & 53.20 & 7.0 \\
\hline $\mathrm{NCH}_{2} \mathrm{CH}_{2} \mathrm{OC}_{6} \mathrm{H}_{4}\left(\mathrm{OCH}_{2} \mathrm{CH}_{3}\right)-2$ & $4.54(t, 2 H)$ & 63.85 & 4.6 \\
\hline $\mathrm{NCH}_{2} \mathrm{CH}\left(\mathrm{OCH}_{2} \mathrm{CH}_{3}\right) 2$ & $4.70(\mathrm{~d}, 2 \mathrm{H})$ & 64.07 & 5.3 \\
\hline $\mathrm{NCH}_{2} \mathrm{CH}\left(\mathrm{OCH}_{2} \mathrm{CH}_{3}\right) 2$ & $5.10(t, 1 H)$ & 69.09 & 5.3 \\
\hline $\mathrm{NCH}_{2} \mathrm{CH}_{2} \mathrm{OC}_{6} \mathrm{H}_{4}\left(\mathrm{OCH}_{2} \mathrm{CH}_{3}\right)-2$ & $5.21(t, 2 H)$ & 101.64 & 4.1 \\
\hline $\begin{array}{l}\text { Hs and Cs of benzimidazole and } \\
\text { phenoxy rings }\end{array}$ & $\begin{array}{c}6.68-6.77,7.23-7.35 \\
7.59-7.61 \text { and } 7.81-7.83(\mathrm{~m}, \\
8 \mathrm{H})\end{array}$ & $\begin{array}{c}\text { 112.55, 112.93, 113.05, } \\
\text { 114.04, 120.79, 121.93, } \\
\text { 124.50, 124.74, 134.09, } \\
134.36,147.82 \text { and } 148.75\end{array}$ & - \\
\hline$A g-C(2)_{\text {carbene }}$ & - & 190.94 & - \\
\hline
\end{tabular}

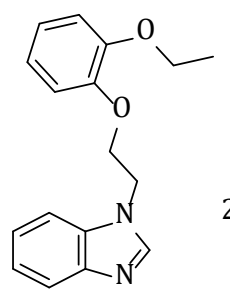

2,2-Diethoxyethyl bromide<smiles>CCOC(Cn1c(Br)nc2ccccc21)OCC</smiles><smiles>CCOc1ccccc1OCCN1c2ccccc2N(CC(OCC)OCC)C1C(Cl)Cl</smiles>

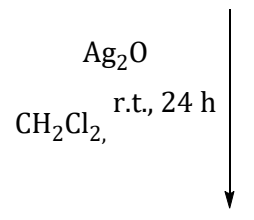<smiles>CCOc1ccccc1O</smiles><smiles>CCCn1[nH]c2ccccc21</smiles>

(1)

(3)<smiles>CCOc1ccccc1OCCN1c2ccccc2N(CC(OCC)OCC)C1C(Br)(Br)Br</smiles>

Sheme 2. Synthesis of benzimidazolium salt (1), Ag-NHC complex (2) and Au-NHC complex (3). 


\section{Synthesis of [1-(2-(2-Ethoxyphenoxy)ethyl)-3- (2,2-diethoxyethyl)benzimidazol-2-ylidene]gold(I) chloride, (3)}

Gold complex (3) synthesized by the transmetalation method from $\left[\mathrm{AuCl}\left(\mathrm{PPh}_{3}\right)\right]$ and silver-NHC complexes. Silver complex (2) $(0.29 \mathrm{~g}, 0.5 \mathrm{mmol})$ was dissolved in dichloromethane $(15 \mathrm{~mL})$ and $\left[\mathrm{AuCl}\left(\mathrm{PPh}_{3}\right)\right](0.25 \mathrm{~g}, 0.5$ mmol) was added. The solution was stirred at $25^{\circ} \mathrm{C}$ for $24 \mathrm{~h}$. End of the reaction, the solution was filtered over Celite. Half of the solution was evaporated in vacuo and $\mathrm{Et}_{2} \mathrm{O}(15 \mathrm{~mL})$ was added to crystallize. The resulting white crystals were obtained in high yield. The structure of compound 3 was characterized by ${ }^{1} \mathrm{H}$ and ${ }^{13} \mathrm{C}$ NMR spectroscopic methods (Table 3). (0.44 g, yield 70\%; m.p. $\left.=125-126^{\circ} \mathrm{C} ; \mathrm{FT}-\mathrm{IR} \mathrm{v}_{(\mathrm{CN})}=1403 \mathrm{~cm}^{-1}\right)$.

\section{CONCLUSION}

In this study, the new benzimidazolium salt (1) containing ether functionalized alkyl group as the NHC ligand precursor was synthesized. Ag-NHC complex (2) was synthesized by interaction of this ligand precursor with $\mathrm{Ag}_{2} \mathrm{O}$. The Ag-NHC complex readily converted into the corresponding Au-NHC complex by transmetallation method. The structures of all synthesized compounds were characterized by appropriate spectroscopy methods. In later studies, synthesized benzimidazolium salt (1), Ag-NHC complex (2) and Au-NHC complex (3) will be used in different medical applications as pharmaceutical agents. If successful results are obtained, it is planned to synthesize new NHC ligands and their metalcomplexes with different properties by improving the structure diversity of these compounds.

\section{References}

1. X. Hu, I. Castro-Rodriguez, K. Olsen, K. Meyer, Group 11 metal complexes of $\mathrm{N}$-heterocyclic carbene ligands: Nature of the metal carbene bond, Organometallics, 23 (2004) 755764.

2. D. Nemcsok, K. Wichmann, G. Frenking, The significance of $\pi$ interactions in group 11 complexes with $N$-heterocyclic carbenes, Organometallics, 23 (2004) 3640-3646.

3. S. Patil, A. Deall, B. Gleeson, F. Hackenberg, H. Müller-Bunz, F. Paradisi, M. Tacke, Synthesis, cytotoxicity and antibacterial studies of novel symmetrically and non-symmetrically p-nitrobenzyl-substituted $N$-heterocyclic carbene silver(I) acetate complexes, Z. Anorg. Allg. Chem., 637 (2011) 386396.

4. S.Y. Hussaini, R.A. Haque, M.R. Razali, Recent progress in silver(I)-, gold(I)/(III)- and palladium(II) - $N$-heterocyclic carbene complexes: A review towards biological perspectives, J. Organomet. Chem., 882 (2019) 882:96-111.

5. N.A. Johnson, M.R. Southerland, W.J. Youngs. Recent Developments in the Medicinal Applications of Silver-NHC Complexes and Imidazolium Salts, Molecules, 22 (2017) 1263-1282.

6. S. Medici, M. Peana, G. Crisponi, V.M. Nurch, JI. Lachowicz, M. Remelli, M.A. Zoroddu, Silver coordination compounds: A new horizon in, Coord. Chem. Rev., 327-328 (2016) 349-359.

7. L. Kaps, B. Biersack, H. Müller-Bunz, K. Mahal, J. Münzner, M. Tacke, T. Mueller, R. Schobert, Gold(I)-NHC complexes of antitumoral diarylimidazoles: Structures, cellular uptake routes and anticancer activities, J. Inorg. Biochem., 1(106) (2012) 52-58.

8. A. Gautier, F. Cisnetti, Advances in metal-carbene complexes as potent anti-cancer agents, Metallomics, 4 (2012) 23-32.

9. L.Oehninger, R. Rubbiani, I. Ott, $N$-Heterocycliccarbenemetal complexes in medicinal chemistry, Dalton Trans., 42 (2013) 3269-3284.

10. M. Juntti, D. medicine Russel, J. Turnpenny, Evidence, politics and power in public policy for the environment, Enviroment. Sci. \&Policy, 12 (2009) 207-215.

11. A.B.G. Lansdown, A review of the use of silver in wound care: facts and fallacies, British J. Nursing, 13 (2004) S6.

12. A. Melaiye, W. Youngs, Silver and its application as an antimicrobial agent, Expert Opin. on Ther. Patents, 15 (2005) 125-130

13. E.R. Jamieson, SJ. Lippard, Structure, recognition, and processing of cisplatin DNA adducts, Chem. Rev., 99 (1999) 2467-2498.

14. G. Chu, Cellular responses to cisplatin. The roles of DNAbinding proteins and DNA repair, J. Bio. Chem, 269 (1994) 787-790.

15. C.G. Hartinger, P.J. Dyson, Bioorganometallic chemistry from teaching paradigms to medicinal applications, Chem. Soc. Rev., 38 (2009) 391-396.

16. S.P. Fricker, Medical uses of gold compounds: Past, present and future, Gold Bulletin, 29 (1996) 53-60.

17. R.S. Melaiye, A. Simons, F. Milsted, C. Pingitore, C.A. Wesdwmiotis, Tessier, W.J. Youngs, Formation of WaterSoluble Pincer Silver(I) -Carbene Complexes: A Novel Antimicrobial Agent, J. Med. Chem., 47 (2004) 973-977. 